\title{
Study of the species composition and population structure of winter wheat leaf blotch pathogens in the central chernozem region of the Russian Federation
}

\author{
Yu.V. Zeleneva ${ }^{1,2, *}$, V.P. Sudnikova ${ }^{1}$ \\ ${ }^{1}$ Middle-Russian affiliate of the Federal Research Center named after I.V. Michurin, Tambov, the \\ Russian Federation \\ ${ }^{2}$ Federal State Budgetary Institution "All-Russian Institute of Plant Protection", Saint Petersburg, \\ Pushkin, the Russian Federation
}

\begin{abstract}
For the period of 2020, the species composition of winter wheat leaf blotch pathogens on the territory of the Central Chernozem region was studied. It is shown that the Zymoseptoria tritici species dominates in the pathogenic complex during all phases of wheat vegetation. Under the conditions of the year, the other two species - the pathogen of the disease: Parastagonospora nodorum and Parastagonospora avenae f. sp. triticea had no economic significance. The populations of the species Zymoseptoria tritici, formed on winter and spring wheat cultivats according to morphological, physiological and pathogenic properties, were studied. It is shown that black corrugated colonies with an average growth rate and high sporulation predominate. Using monogenic lines, virulence phenotypes were determined in isolates taken from infectious wheat material. Seven virulence phenotypes were identified. All isolates hit the test lines from 2 to 4 points, therefore they were characterized by wide virulence and high aggressiveness. The information obtained is necessary for the development of a methodology for resistance breeding.
\end{abstract}

\section{Introduction}

An increase in grain production is possible if losses from environmental stress factors are reduced. In zones favorable for the cultivation of grain crops, the main harm is usually caused by pathogens. The composition of their pathogenic complexes is not the same in different regions. In the grain agrophytocenosis of the CCR, among the diseases that limit the receipt of a consistently high yield by years and profitability of grain production are (in descending order of harmfulness) septoria spots, brown rust, head smut of wheat, helminthosporium diseases and barley smut. The ecological, economic and social significance of the creation and zoning of resistant varieties is well known. The scientific,

*Corresponding author: zelenewa@mail.ru 
theoretical and methodological basis of plant breeding for disease resistance is the constant monitoring of the relationships developing in the agrophytocenosis in the plant-host pathosystem - pathogen.

Septoria blight is one of the harmful and widespread wheat diseases. There are three main pathogens of the disease on the territory of Russia. The first species - Zymoseptoria tritici (Desm.) Quaedvlieg \& Crous (teleomorph: Mycosphaerella graminicola (Fuckel) J. Schroet)) [1], causes septoria of wheat leaves. It belongs to the family Mycosphaerellaceae. This species dominates and is the most harmful in the southern regions: in the North Caucasus, in the Lower Volga region, in the Central Chernozem region [2, 3, 4, 5, 6]. Two other species: Parastagonospora nodorum (Berk.) (teleomorph: Leptosphaeria nodorum E. Müll., synonym: Phaeosphaeria nodorum (E. Müll) Hedjar.) and Parastagonospora avenae Bissett f. sp. triticea T. Johnson belong to the Phaeosphaeriaceae family [1]. The species Parastagonospora. nodorum -causes septoria blight of wheat leaves and ears. It is ubiquitous, same as the species Zymoseptoria tritici, but until recently it dominated and was most harmful in the Northwestern and Volga-Vyatka regions [2, 3, 4]. Currently, the distribution of the Zymoseptoria tritici species and its dominance in the pathogenic complex of septoria spots in the fields of Pskov, Novgorod, Leningrad, and Moscow regions is being observed [7, 8]. The species Parastagonospora avenae f. sp. triticea, as practice shows, is registered in wheat crops by the end of the growing season on leaves, stems and ears. In this regard, there is no unambiguous opinion about its economic significance.

Due to climate fluctuations, many scientists note changes occurring in the spread of invasive fungi [9-14].

There is information in the literature that the species Zymoseptoria tritici develops better at a temperature of $+16-+25^{\circ} \mathrm{C}$ [15]. We have shown that the warm temperature regime of May and April has a positive effect on the frequency of the species Zymoseptoria tritici. [16]. Cooler days of these months will affect the better development of the species Parastagonospora avenae triticea and Parastagonospora nodorum. The optimal temperature range for the species $S$. nodorum is $+12-+26^{\circ} \mathrm{C}$, that is, the lower limit is $4^{\circ} \mathrm{C}$ lower than for Zymoseptoria tritici [17, 18]. The species Parastagonospora nodorum receives preferential development in years with wetter weather during the growing season of wheat, in contrast to the species Zymoseptoria tritici, which is more resistant to reduced humidity indicators [16]. The obtained data demonstrate the pathogen adaptation to the conditions of increasing the temperature regime and reducing the amount of precipitation.

Systematic monitoring of the population structure of phytopathogens is the basic stage of the measures taken to obtain environmentally friendly products in a changing climate. It allows to determine the range of economically significant diseases of agricultural crops for the region.

The purpose of the research is to study the morphological, physiological and pathogenic properties of populations of the species Zymoseptoria tritici for the development of a methodology for resistance breeding.

\section{Materials and Methods}

To study the pathogenic complexes of pathogens, reconnaissance surveys of production and breeding and seed-growing plantings of grain crops in 2020 in the Central Chernozem region (Tambov, Lipetsk, Voronezh, Kursk, Belgorod regions) were conducted. During the process of collecting the material and phytosanitary examination, we were guided by the recommendation published under the editorship of S.S. Sanin [19]. 
Mycological examination was carried out using the determinants of fungi by M.N. Pidoplichko [20].

The cultivation of pathogen isolates of septoria blight and the study of their morphological and physiological properties were carried out according to the methods of VNIIF [21] and the Central Russian branch of the TNIISKh [22].

The pathogenic properties of the isolates of Zymoseptoria tritici were determined on a set of test cultivars: Mironovskaya 808, Kharkovskaya 46, Orenburgskaya 10, Prokhorovka, Bezenchukskaya 182, Bezenchukskaya 200 virulence on monogenic lines $S t b 1, S t b 2, S t b 3, S t b 4, S t b 5, S t b 7$ [23]. A laboratory evaluation method was used on isolated wheat leaves according to previously developed methods [23-24]. The octal system was used to indicate the virulence phenotypes of the pathogen [25].

Statistical data processing was carried out using the computer program "STATISTICA".

\section{Results and Discussion}

Constant monitoring of the species composition of septoria blight pathogens allows to identify the areas of the main species of septoria, to determine the dominant species of the fungus in a particular region, against which protective measures should be carried out, to track the dynamics of species in time and space.

When planning crop surveys, the ontogenetic association of different pathogens with certain phases of plant vegetation was considered. On wheat in the first half of the growing season (tillering-booting), the species Zymoseptoria tritici usually dominates. The pathogen Parastagonospora nodorum manifests itself more intensively in the earing-flowering phase. After the appearance of the ear, Parastagonospora avenae triticea can also be found. Therefore, in order to study the species composition, samples were collected during the period from earing-flowering to grain filling, when the pathogen reached the most intensive development, and all the main species are present on the crops.

Of the three types of septoria blight found on wheat crops, the greatest damage to the crop is caused by Zymoseptoria tritici, which parasitizes plants from the tillering phase to full ripeness with a high degree of damage. The pathogen Parastagonospora nodorum manifests itself more intensively in the earing-flowering phase and then spreads to the flag leaf and ear. After the appearance of the ear, Parastagonospora avenae triticea can be found, which is mainly found on aging tissues. In 2020, the frequency of $S$. nodorum and $S$. avenae species was low, so their impact on the yield was insignificant. Thus, the frequency of septoria blight species on winter wheat in the CCR was: Zymoseptoria tritici $-88.7 \%$, Parastagonospora nodorum - 8.4\%, Parastagonospora avenae triticea - 2.9\%; on spring wheat - Zymoseptoria tritici - 69.8\%, Parastagonospora nodorum - $23.4 \%$, Parastagonospora avenae triticea - 6.5\%. The influence of the cultivar on the species composition of the septoria blight pathogens is traced.

The analysis of intraspecific differentiation of the population of wheat septoria blight Zymoseptoria tritici by crop and morphological characteristics was carried out according to three main criteria: appearance and structure of colonies; growth rate of colonies on potatodextrose agar (PDA); intensity of sporulation of the fungus in vitro.

In total, 47 isolates of the fungus from spring and 31 winter wheat cultivars were studied.

According to the appearance and nature of the structure, the colonies of isolates taken from zoned wheat cultivars in the CCR were represented by three morphotypes: yeast-like, mixed and mycelial. Within each morphotype, the colonies varied in color. The yeast-like 
type of colonies ( $\mathrm{Ib}$ - black, corrugated) dominated on the cultivars of winter and spring wheat.

It was found that isolates dominated in the population of Zymoseptoria tritici isolated from spring and winter wheat cultivars, forming colonies on PDA with an average growth rate $(\mathrm{d}=10-15 \mathrm{~mm})$.

According to the intensity of sporulation on the nutrient medium, the isolates of Zymoseptoria tritici were divided into three groups.

Highly sporulating colonies ( $>120$ million spores $\left./ \mathrm{cm}^{2}\right)$ were observed among isolates, selected from cultivars, forming yeast type colonies in PDA (winter wheat cultivars: Almira, Volzhskaya K, Donskaya Lira, Don 93, Donskaya bezostnaya, Zvonnitsa, Odesskaya 200, Odesskaya 267, Chernozemka 115; varieties of spring wheat: Voronezhskaya 10, Daria, Prokhorovka, Udacha). The frequency of highly sporulating colonies varied from 22\% (Volzhskaya K) to 60\% (Almira, Donskaya Lira).

Medium-sporulating colonies (30-120 million spores $/ \mathrm{cm}^{2}$ ) were noted among all isolates picked from both winter and spring wheat cultivars, their frequency ranged from 10 to $50 \%$. The exceptions were isolates from the cultivars Surava, Skipetr, KVS Torridon, among which there were no colonies with average sporulation.

Weakly sporulating colonies $\left(<30\right.$ million spores $\left./ \mathrm{cm}^{2}\right)$ were present among the isolates taken from the cultivars Odesskaya 200, Surava and Skipetr, KVS Torridon.

Highly sporulating yeast-like colonies were included in the study of pathogenic properties. Pathogenic properties of isolates include qualitative (virulence) and quantitative (aggressiveness) characteristics.

Using monogenic lines, the virulence phenotypes were determined in thirteen isolates from the infectious material of zoned winter wheat cultivars and in seven isolates from spring wheat (Table 1, Figure 1).

Table 1. Virulence phenotypes of Zymoseptoria tritici isolates selected from zoned wheat cultivars.

\begin{tabular}{|c|c|c|c|c|c|c|c|c|}
\hline \multirow[t]{2}{*}{ Host cultivar } & \multicolumn{6}{|c|}{$\begin{array}{c}\text { Reaction of monogenic lines to } \mathrm{S} \text {. tritici } \\
\text { infection }\end{array}$} & \multirow{2}{*}{$\begin{array}{c}\text { No. } \\
\text { of } \\
\text { phenotype } \\
\text { of } \\
\text { virulence }\end{array}$} & \multirow{2}{*}{$\begin{array}{c}\text { Group } \\
\text { of } \\
\text { pathogenicit } \\
y\end{array}$} \\
\hline & Stb 1 & Stb 2 & Stb 3 & Stb 4 & Stb 5 & Stb 7 & & \\
\hline \multicolumn{9}{|c|}{ Winter wheat } \\
\hline Almera & 3 & 3 & 1 & 2 & 3 & 4 & 33 & II \\
\hline Basalt & 3 & 3 & 4 & 4 & 4 & 1 & 73 & II \\
\hline Volzhskaya 100 & 3 & 2 & 2 & 3 & 3 & 1 & 13 & II \\
\hline Volzhskaya K & 4 & 4 & 3 & 4 & 4 & 1 & 73 & II \\
\hline Donskaya Lira & 3 & 3 & 4 & 4 & 3 & 1 & 73 & II \\
\hline Don 93 & 4 & 4 & 3 & 3 & 3 & 3 & 77 & III \\
\hline Zvonnitsa & 4 & 1 & 2 & 2 & 1 & 2 & 10 & II \\
\hline Inna & 4 & 1 & 2 & 2 & 4 & 2 & 11 & II \\
\hline Skipetr & 1 & 4 & 2 & 2 & 3 & 2 & 11 & II \\
\hline Chernozemka 115 & 1 & 1 & 4 & 2 & 3 & 1 & 11 & II \\
\hline Next sample & 1 & 4 & 2 & 3 & 2 & 4 & 13 & II \\
\hline Bezenchukskaya 380 & 1 & 1 & 4 & 4 & 1 & 2 & 11 & II \\
\hline Surava & 4 & 2 & 2 & 4 & 4 & 4 & 17 & II \\
\hline $\begin{array}{l}\text { Frequency of } \\
\text { occurrence in } \%\end{array}$ & 69.2 & $\begin{array}{c}53 . \\
8\end{array}$ & \begin{tabular}{c|c}
46. \\
2
\end{tabular} & 61.5 & 76.9 & 30.8 & - & - \\
\hline \multicolumn{8}{|c|}{ Spring wheat } & \\
\hline
\end{tabular}




\begin{tabular}{|l|c|c|c|c|c|c|c|c|}
\hline Prokhorovka & 4 & 2 & 3 & 2 & 3 & 2 & 31 & II \\
\hline Udacha & 2 & 2 & 3 & 2 & 2 & 2 & 10 & II \\
\hline Voronezhskaya 10 & 1 & 2 & 2 & 1 & 1 & 1 & 00 & I \\
\hline Daria & 2 & 1 & 1 & 2 & 1 & 1 & 00 & I \\
\hline KVS Torridon & 2 & 3 & 3 & 2 & 1 & 1 & 30 & II \\
\hline Yoldyz & 2 & 3 & 4 & 1 & 1 & 1 & 30 & II \\
\hline $\begin{array}{l}\text { Chernozemnouralska } \\
\text { ya }\end{array}$ & 1 & 2 & 1 & 3 & 1 & 1 & 01 & II \\
\hline $\begin{array}{l}\text { Frequency, in \% } \\
\text { P. }\end{array}$ & 14.3 & $\begin{array}{c}28 . \\
6\end{array}$ & $\begin{array}{c}57 . \\
1\end{array}$ & 14.3 & 14.3 & 00 & - & - \\
\hline
\end{tabular}

Seven virulence phenotypes were identified among isolates taken from thirteen winter and five spring cultivars. The winter cultivars were dominated by the 11 phenotype found on four cultivars. On spring wheat, most of the phenotypes were recorded 1-2 times.

The diversity of the isolated phenotypes in virulence indicates the heterogeneity of the pathogen Zymoseptoria tritici and the influence of the host cultivar on virulence.

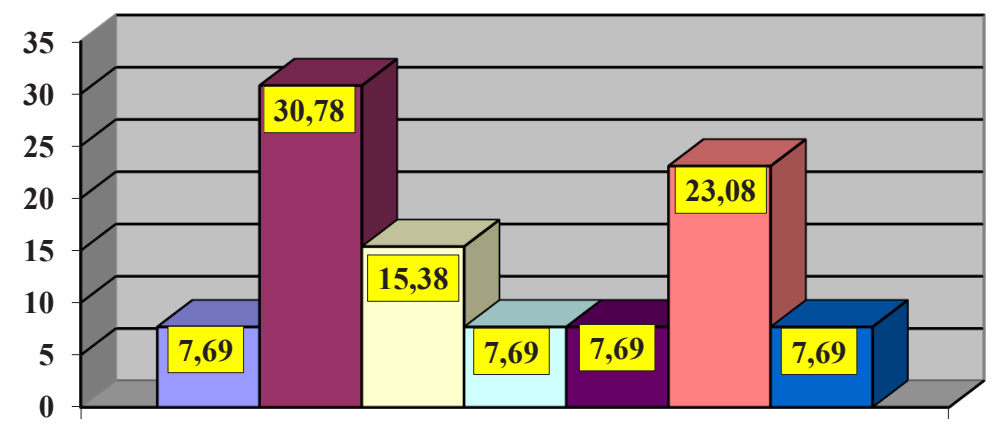

Winter wheat

\begin{tabular}{|lllllll|}
\hline$\square 10$ & $\square 11$ & $\square 13$ & $\square 17$ & $\square 33$ & $\square 73$ & $\square 77$ \\
\hline
\end{tabular}

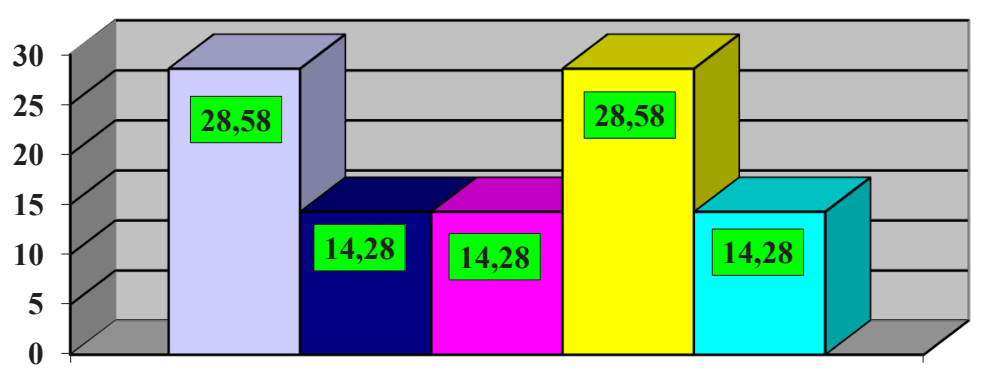

Spring wheat

$\square 0 \quad \square 1 \quad \square 10 \quad \square 30 \quad \square 31$

Fig. 1. Frequency of virulence phenotypes on wheat cultivars of the Zymoseptoria tritici population. 


\section{Conclusion}

In 2020, the morphological and crop properties of Zymoseptoria tritici populations were studied - morphotype, colony growth rate, sporulating ability in vitro. It was revealed that the pathogen population is represented by ten morphotypes. Yeast-like colonies prevailed: black corrugated. Yeast-like colonies had the highest sporulating ability. The structure of the population was dominated by isolates forming PDA colonies with medium growth rate.

Yeast-like colonies isolated from infected winter wheat cultivars on a set of monogenic lines were differentiated into 12 phenotypes. All isolates hit the test lines from 2 to 4 points, therefore they were characterized by wide virulence and high aggressiveness.

Experimental data on the structure of pathogenic properties of populations of wheat septoria blight pathogens indicate that the genes have a wide virulence and high aggressiveness.

\section{Acknowledgements}

This research was carried out and published with the support of the Regional Competition "Grants to support applied research of young scientists in 2020" "Study of ways to prevent epiphytotic development of wheat diseases in the conditions of the Central Black Soil Region (on the example of Septoria leaf spot, brown rust, dust smut and stinking smut)" Project No. 27MU-20 (02).

\section{References}

1. Mycobank, http://www. mycobank.org (Accessed: 06.06.21)

2. A.A. Sanina, L.V. Antsiferova, L.M. Suprun, Mycology and phytopathology 20 (4), 300-306 (1986)

3. A.A. Sanina, L.V. Antsiferova, Mycology and phytopathology 25 (3), 250-252 (1991)

4. E.V. Pakholkova, E.A. Akimova, S.S. Sanin, S.B. Goodwin, Anniversary collection of works of VNIIF 65 (2008)

5. T.I. Borzionova, M.N. Vasetskaya, V.P. Sudnikova, H.A. Alipbekova, Siberian Bulletin of Agricultural Science 3, 106 (1991)

6. V.P. Sudnikova, S.A. Artemova, Yu.V. Zeleneva, Agro XXI 10-12, 30-32 (2007)

7. E.I. Gultyaeva, E.L. Shaidayuk, M.M. Levitin, I.V. Maslova, O.A. Kolesnikova, M.P. Vusatyuk, Plant protection and quarantine 5, 30-31 (2019)

8. E.V. Pakholkova, N.N. Salnikova, N.A. Kurkova, In the collection: Biological plant protection-the basis for the stabilization of agroecosystems. materials of the International Scientific and Practical Conference 123-127 (2018)

9. M.M. Levitin, Epidemics of plant diseases: monitoring, forecast, control. Materials of the International Conference. Bolshye Vyazemye of the Moscow region, 18-30 (2017)

10. Yu.T. Dyakov, M.M. Levitin, Infestations of phytopathogenic fungi 260 (2018)

11. S.M. Coakley, H. Scherm, S. Chakraborty, Annu. Rev. Phytopathol 37, 399-426 (1999)

12. K.A. Garrett, S.P. Dendy, E.E. Frank, M.N. Rouse, S.E. Travers, Genomes to Ecosystems. Annu. Rev. Phytopathol 44, 489-509 (2006) 
13. K.A. Garrett, M. Nita, E.D. DeWolf, L. Gomez, A.H. Sparks, In: Climate Change: Observed Impacts on Planet Earth, Letcher, T. (ed.), Elsevier, Dordrecht 425-437 (2009)

14. O.S. Afanasenko, M.M. Levitin, NJF Report 8 (7), 49-50 (2012)

15. Z. Eyal, A.L. Scharen, J.M. Prescott, M. Van Ginkel, The Septoria Diseases of Wheat: Concepts and Methods of Management, 89 (CIMMYT, Mexico, 1987)

16. Yu.V. Zeleneva, Dissertation for the degree of Doctor of Biological Sciences AllRussian Research Institute of Plant Protection 473 (Saint Petersburg-Pushkin, 2019)

17. W.A. Shipton, W.R.J. Boyd, A.A. Rosielle, B.I. Shearer, Bot. Rev 37, 231-262 (1971)

18. M. Babodoost, T.T. Hebert, Phytopathology 74 (5), 592-595 (1984)

19. S. Sanin, Since, Phytosanitary examination of grain crops (plant diseases): Recommendations, 138 (Moscow Kolos, 2002)

20. M.N. Pidoplichko, Determinant. 3, Pycnidial mushrooms, 232 (Kiev "Nauka dumka", 1978)

21. A.A. Sanina, Mycology and phytopathology 2, 25 (1991)

22. V.P. Sudnikova, Yu.V. Zeleneva, V.V. Plakhotnik, Methodological recommendations Tambov Publishing House of TSU named after G. R. Derzhavin 35 (2011)

23. E.V. Pakholkova, N.A. Salnikova, A.A. Sanina, Materials of the International scientific and Practical Conference dedicated to the 125th anniversary of the birth of N.I. Vavilov. Bolshye Vyazemye of the Moscow region 106-110 (2012)

24. A.A. Sanina, L.V. Antsiferova, Mycology and phytopathology 25 (2), 155-160 (1991)

25. E. Limpert, K. Muller, Phytopathology 140, 346-358 (1994) 